\title{
Comparative study on individual aromatase inhibitors on cardiovascular safety profile: misleading analysis and doubtful methodology
}

This article was published in the following Dove Press journal:

OncoTargets and Therapy

20 November 2015

Number of times this article has been viewed

\section{Wenqin Guo \\ Lang Li}

Department of Cardiology, The First Affiliated Hospital of Guangxi Medical University, Nanning, People's Republic of China
Correspondence: Lang Li Department of Cardiology, The First Affiliated Hospital of Guangxi Medical University, 22 Shuangyong Road, Nanning 53002I, People's Republic of China

Tel +86 77| 533 | I7 |

Fax $+8677 \mid 535980$ I

Email gmxu2015@I63.com

\section{Dear editor}

Zhao et al have presented the result of the relative cardiovascular safety profile in using anastrozole, letrozole, and exemestane to treat the postmenopausal estrogen receptorpositive breast cancer, in which fatal or nonfatal myocardial infarction is the outcome measure and ten randomized controlled trials are used as the data sources. ${ }^{1}$ We congratulate and applaud their important work, but there are some issues of concern.

First, the difference in duration of adjuvant tamoxifen therapy among the studies led to heterogeneity and inconsistency. For instance, the duration of tamoxifen therapy was 2 years in the TEAM (Tamoxifen Exemestane Adjuvant Multinational) trial, whereas it was 5 years in the ATAC (Arimidex, Tamoxifen, Alone or in Combination) trial. In fact, the duration of tamoxifen therapy is relevant to toxicity. The practice of "lumping" cotreatments together generally makes no sense in clinical practice. ${ }^{2}$ In addition, the author regarded the sequential therapy (tamoxifen for 2 years followed by anastrozole for 3 years) or the extended adjuvant therapy (tamoxifen for 5 years followed by anastrozole for 3 years) as the anastrozole group, which was misleading. In fact, the tamoxifen would have the "crossover" effect even after the completion of the 2-, 3-, or 5-year treatment period. Instead, the author should have considered comparing the safety prolife among the initial aromatase inhibitor therapy, sequential therapy, and extended therapy, which would be of a more meaningful clinical significance.

Second, the authors failed to include three relevant randomized controlled trials in their meta-analysis, although they apparently met their inclusion criteria. ${ }^{3-5}$

Third, there was one important methodological issue in this review. The reporting of the inconsistency between the direct and indirect comparison is laudable in a network meta-analysis. However, this review did not describe the methodology of the inconsistency analysis in the "Statistical analysis" section.

Finally, in Figure 3, it was described that both severe and total cardiovascular risk deviance information criterion values were $<200$, which means that the calculated results were convincible. We are interested in the source of this perspective. In addition, the methodology of model fit was not confirmed in the "Statistical analysis" section.

\section{Disclosure}

The authors report no conflicts of interest in this communication.

\section{References}

1. Zhao X, Liu L, Li K, Li W, Zhao L, Zou H. Comparative study on individual aromatase inhibitors on cardiovascular safety profile: a network meta-analysis. Onco Targets Ther. 2015;8:2721-2730. 
2. Ades AE, Caldwell DM, Reken S, Welton NJ, Sutton AJ, Dias S. Evidence synthesis for decision making 7: a reviewer's checklist. Med Decis Making. 2013;33(5):679-691.

3. Bonneterre J, Thurlimann B, Robertson JF, et al. Anastrozole versus tamoxifen as first-line therapy for advanced breast cancer in 668 postmenopausal women: results of the Tamoxifen or Arimidex randomized group efficacy and tolerability study. J Clin Oncol. 2000;18(22): 3748-3757.

4. Nabholtz JM, Buzdar A, Pollak M, et al. Anastrozole is superior to tamoxifen as first-line therapy for advanced breast cancer in postmenopausal women: results of a North American multicenter randomized trial. Arimidex Study Group. J Clin Oncol. 2000;18(22):3758-3767.
5. Paridaens RJ, Dirix LY, Beex LV, et al. Phase III study comparing exemestane with tamoxifen as first-line hormonal treatment of metastatic breast cancer in postmenopausal women: the European Organisation for Research and Treatment of Cancer Breast Cancer Cooperative Group. J Clin Oncol. 2008;26(30):4883-4890.

Dove Medical Press encourages responsible, free and frank academic debate. The content of the OncoTargets and Therapy 'letters to the editor' section does not necessarily represent the views of Dove Medical Press, its officers, agents, employees, related entities or the OncoTargets and Therapy editors. While all reasonable steps have been taken to confirm the content of each letter, Dove Medical Press accepts no liability in respect of the content of any letter, nor is it responsible for the content and accuracy of any letter to the editor.

\section{Publish your work in this journal}

OncoTargets and Therapy is an international, peer-reviewed, open access journal focusing on the pathological basis of all cancers, potential targets for therapy and treatment protocols employed to improve the management of cancer patients. The journal also focuses on the impact of management programs and new therapeutic agents and protocols on

\section{Dovepress}

patient perspectives such as quality of life, adherence and satisfaction. The manuscript management system is completely online and includes a very quick and fair peer-review system, which is all easy to use. Visit http://www.dovepress.com/testimonials.php to read real quotes from published authors. 